\title{
Not Just Book Week: Developing A Reading Culture At Mill Park Secondary College
}

\author{
Judith Way. \\ Mill Park Secondary College \\ Melbourne \\ AUSTRALIA
}

\begin{abstract}
Establishing a culture where reading is valued as much as participation in sporting teams is not easy. At Mill Park Secondary School a programme has been underway for three years and appears to be making strong progress in cultural change. This presentation outlines three initiatives that are working well together. They target teachers, students and parents and are suplemented by Reading Cup team activities and Reading Challenge activities for individuals.
\end{abstract}

\section{Introduction}

There is nothing wrong with celebrating Book Week. In Australia each year we celebrate the winning authors and illustrators of five categories in our Children's Book Council Book of the Year Award in August. Many schools invite authors to speak to students, have dress-up parades where children come dressed as their favourite character. have Book Week quizzes and competitions and involve the whole school in activities such as 'Drop Everything and Read' where all school students and staff read for the first twenty minutes of each day. Book Week is great. It is wonderful to celebrate reading as a whole school and it is fantastic to acknowledge Australian authors and illustrators at the top of their profession and their contribution to Australian children's literature.

But celebrating Book Week is not enough. To me, every week is book week. One week a year does not do justice to what books can do for children, and what we, as teachers, librarians and teacher librarians (or library media specialists) can do to bring students and books together.

Due to literacy test results and anecdotal evidence from both teachers in general and my own observations, I concluded that my school, Mill Park Secondary College, needed to develop a reading culture, where reading was accepted in the same way as sport and held as much excitement and participation. Developing a reading culture, or any other culture is not easy. Changing the long and tightly held tradition of sporting prowess as king in sports mad Melbourne was never going to be easy, nor a short term process. We needed a number of different initiatives, that would appeal to a range of students (and staff) and we needed to continue these initiatives week in, week out. We decided that we could only implement a culture change by focussing on all members of the school community - students, staff and parents. We wanted to surround our school community with books and target reading as a 'normal' thing to talk about and become excited about.

The Australian Macquarie Dictionary defines culture as: 
- Development or improvement by education or training;

- Enlightenment or refinement resulting from such development;

- The sum total way of living built up by a group of human beings.

That was what we wanted to happen at Mill Park. We wanted to make an improvement in literacy; we wanted students, staff and parents to gain enlightenment from the improvement and we wanted reading to be an ingrained part of our school culture.

\section{Initiative 1: Staff book club.}

As we wanted to obtain all three of these outcomes for our school community, our first initiative was a 'Staff Book Club'. It wasn't my idea - a couple of teacher librarians from Vermont Secondary College in Melbourne presented the idea at a School Library Association of Victoria conference about 5 years ago. We introduced a 'Staff Book Club' on a voluntary basis where staff were asked to read one and review young adult title per term. We decided to aim the Staff Book Club at teachers and other members of staff based at our junior campus (years 7-10) as we had more influence over books that would be selected for students to study. We knew that we needed more contemporary and engaging books on our booklist for students to study as a class. Reading and recommending new young adult fiction to each other was a way to build up our resources. We usually met in a very informal manner - sometimes at a staff member's house where we all brought a dish, sometimes at a cafë and sometimes in the library after school - with wine and cheese of course! Being informal meant that staff were not threatened by the concept. The idea of the Staff Book Club is that everyone reads a different book and then reviews it at the meeting. Much of the focus is on whether or not the book would be suitable for classroom study, whether it would appeal to both boys and girls and if it would complement the areas of study already set down by the English department. Books that were recommended highly would be purchased to replace the classic, but uninspiring novels that had been used for a number of years.

Sometimes reviews are written, some teachers don't get the time, but their interest, knowledge and enthusiasm for young adult literature has certainly expanded dramatically. The main aim is to have staff attend an informal meeting once a term and read more young adult fiction.

You may think that having staff read young adult fiction at a secondary college should be a given. However, we discovered English teachers were not reading young adult novels and, as a result, it was difficult for them to be informative and enthusiastic in encouraging their students to read. Through provision of a casual setting for discussion, a number of staff became keen to attend and provide book reviews. It was heartening to have members of the Science and the German faculties attend. If people did not get a chance to read, we still encouraged them to come along. Not only did we want to get staff reading and therefore be more knowledgeable when speaking to their students about reading. we wanted to have a range of successful 'reading role models' available to our students.

\section{Initiative 2: Mini sets.}

Our second initiative was based on 'mini sets' and was aimed at the most important members of the school, the students. By introducing the concept of 'mini sets', where a number of novels are available for students to study in their English class, and making 
selection of the novels open to freer choice, students have a greater chance of success in their English class due to increased engagement. Five copies of approximately 100 titles were chosen for each year level from years 7 to 9 . Students can select their novels in friendship groups or due to interest in the author or information given to them by the teacher librarian in their introductory class. Novels are available to these students for the whole term (approximately 10 weeks.) Student groups then complete a short assignment (such as creation of a PowerPoint presentation or a poster) that 'sells' their book to their classmates. The idea is for the whole topic to be fun and in depth study of the text is not required. Reading for enjoyment is the object.

Many books that had been read and recommended by staff at the Staff Book Club were included in the titles selected for the 'mini sets'. Not only were staff familiar with these novels and could talk to students about them, they were seen as books that would appeal to the students and therefore increase engagement, enjoyment and hopefully to students reading, for example, other titles by their chosen author, or other books that had been reviewed by their classmates.

The concept of mini-sets needed much support from the English department if it was to succeed. After all, the unit was quite unstructured, and that was frightening for some teachers. Against the spirit of the mini sets unit, some teachers devised a lengthy written assignment for students to complete. However, our thoughts were, that at least the teacher was using the mini sets unit with their students. Over time, many of these teachers have gained in confidence with the mini sets unit and allowed students to complete their own short presentation. It was interesting to note that the few teachers who were uncomfortable with the lack of structure of mini sets were ones who did not read young adult fiction, did not come to the Staff Book Club and were unfamiliar with nearly every mini set title available for students to study.

We also needed the English faculty to fund the purchase of the mini set programme. The first four years involved significant funding to establish the programme. We are now on to a maintenance stage where we add approximately ten titles per level per annum, as well as replacing lost copies of current mini sets. In 2003, it was decided to pass on the cost of the mini sets to parents and now a $\$ 5$ charge per student is levied on the school booklist. It was felt that $\$ 5$ was a reasonable fee, and the money raised would mean the ongoing development of the mini set strategy for years to come.

\section{Initiative 3: Reading Matters.}

Our final target group within our school community - the parents - have been addressed in our third initiative which we call 'Reading Matters'. We hold voluntary meetings outside of school hours, normally at $6.30 \mathrm{pm}$, once a term. We ask parents and students to attend together. Having parents who read, and discuss reading with students, is very powerful and influential in developing students' literacy skills and valuing of reading.

I compose a short PowerPoint presentation on reading for each meeting. These presentations are quite simplistic, but given the audience we want to attract, we do not want to be too highbrow.

We have high profile 'reading role models', such as professional basketball players, Olympic gold medallists, Australian Football League (AFL) coaches, television presenters 
and authors, to speak to our parents and students about what reading means to them and the type of books they like to read. Sometimes our speakers are more subtle than others, where they talk mainly about their life and achievements, while adding information about their favourite books now and what they liked to read when they were younger. One speaker spoke on reading for nearly the whole hour, but incorporated it in such as way that it interwove with the direction his life had taken and the message was not too didactic.

The evidence at Mill Park Secondary College was that boys lagged far behind girls in literacy and other test results, this issue needed addressing. Having male reading role models speak to the Reading Matters group was a priority when the group first began. We were inspired by Australian author, James Moloney, who in 2000 published a book entitled Boys and hooks. In the book, subtitled 'Building a culture of reading around hols', James gives accessible information on the importance of reading and strategies to get and keep boys reading, from babies to young adults. It is no secret, that so far, nine out of eleven of the speakers that we have had for Reading Matters have been men. $\Lambda$ s we continue the programme, of course it has come to our attention that there are not that many high profile female athletes available to speak to our students. Some have had families and want to concentrate on them. some are not located in Melbourne and we cannot afford to fly them down and accommodate them. And unfortunately, some do not have a high enough profile for our students to actually know and appreciate who they are and what they have achieved.

Part of the Reading Matters programme is to spread the enjoyment of reading, so we have pizza for supper and have a quiz where we give away prizes such as books or movie vouchers. Our guests will pose for photos, sign autographs and chat to the students and parents. The majority of our speakers have been very aecessible to our audience and keen to make a connection with them. If we have authors speak. we sell copies of their books, which helps fund the programme. Currently our budget is AUD $\$ 1500$ per annum.

The first year we introduced Reading Matters, 2002, we did not have any school funding and sold chocolates to raise money to pay for speakers, pizza and prizes. We were fortunate that three of our speakers that year did not charge us a fee. We are also fortunate that one of the speaker ageneies that we deal with, assists us with an extremely good deal in regard to speaker fees, as they appreciate we are not a corporate entity with unlimited funds, but a school trying to make a difference.

Anyone can run this type of programme. Scour the newspapers and see who is an attractive role model for students and find out if they are represented by a speaker agency. The majority of newly retired sports stars want to supplement the income they have lost and are willing to speak to schools for a much lesser fee than they charge corporate organisations. We have a chance of having ex-Australian cricket captain Steve Waugh speak, but have to wait a year or two to get him to speak at our bargain basement prices.

You do not have to have speakers every time. To get the group going. I took quotes from people like tennis players Jim Courier and Venus Williams about reading and presented them on Reading Matters evenings. I wrote to Australian Formula I driver Mark Webber and asked him what type of books he read. Within a month he had responded that he read mainly biographies and autobiographies. Again I presented this information to the students. Some current AFL football players also wrote to our students describing what reading means to them and the books they like to read. 
We were also keen to have one Reading Matters meeting at our new public library. We wanted students to use the municipal library as our school library is only their library for four years whereas the local library will be their library as long as they live in the area. We were fortunate to be welcomed by the staff of the Mill Park Public Library who opened the library on their day off for a Reading Matters meeting in 2002.

We are grateful to the many teachers, especially those from the Physical Education, German, and Maths/Science departments, who attend Reading Matters and who also act as reading role models for their own students. Reading Matters is now incorporated in information given to parents on Parent Information Night and the Campus Principal, among other teachers, encourages parents and students to attend. Often at parent/teacher nights, teachers encourage students, who need some motivation with their reading, to attend Reading Matters. We also advertise Reading Matters to our local primary schools, and judging by the uniforms they wear, several students from a number of our feeder schools are attending.

\section{Reading as a sports activity}

\section{Team event: Readers' Cup}

Our fourth area of 'culture shock' is the Readers' Cup. Dyan Blacklock and Ron McCarthy introduced me to the concept of the Readers' Cup at the Australian Children's Book Council conference in Hobart in October, 2003. The Readers' Cup is a competition where students enter voluntarily, join a team, read a set number of pre-selected books and attend a quiz night. The way it worked last year at Mill Park was that I asked for 16 students (four teams of four) to volunteer. The first four teams to enter were accepted. I selected four novels and ensured that I had four copies of each novel. I chose a selection books that would appeal to boys and girls, and a selection of fiction and autobiography.

All of the students involved attended the quiz night where there were four questions on each of the four books. Then one book was chosen for a creative presentation. Students could choose one of eight options: to develop a game show; design and explain a poster of PowerPoint presentation; compose a song or rap; make and explain a mural; create an $\mathrm{A}-\mathrm{Z}$ of the novel; a "This is your life" presentation; character interviews or a news presentation. Students received one point for each of the following: involvement by each group member; a description of the processes used to develop the activity; knowledge of the story and underlying themes; effort and organisation; creativity; quality success in engaging the audience and completion within five minutes.

One library staff member mentioned to me that students participating in the Readers' Cup had a lot of work to do, but I think of it in terms of school sports team participation. Reading the books over a number of weeks was like going to sports training. The quiz night was like the sports competition day. A member of either sports or reading teams need to demonstrate their commitment to the team and their skill in the area in which they are competing.

The quiz night was a great success. I sent written invitations to students' families and teachers and attendance was excellent. There was a real atmosphere of competition and camaraderic. I asked senior members of staff to judge and as well as having a fun evening, they really saw what a great event the Readers' Cup is. Their support is now assured. 
The reaction to the Readers' Cup this year was so huge that many students were unable to enter a team. We changed the concept so that we had three terms of preliminary rounds where six teams of students fought it out for the right to compete in the fourth term grand final.

At present it appears that Mill Park Secondary College is the only school in Victoria participating in the Readers' Cup. However, we hope to be able to compete against the state winners from Queensland and South Australia in 2005.

\section{Individual event: Reading Challenge.}

We also had students who could not form a team for the Readers' Cup for one reason or another. So we adapted a Reading Challenge that had been developed for the South Australian Premier's Reading Challenge, where students read from a set list of books and earn a certificate, depending on the quantity of books read. Parents sign a form to indicate that their child has read the book.

The library is also committed to donate 10 cents per book read for the Reading Challenge to the international aid agency, War Child. In this way, our students are not only helping themselves by improving their literacy skills, but helping other children less fortunate than themselves. Some students are using the Reading Challenge as an extension to their English work. When they have finished their set work, they go back to the list of books and select another book.

I advertised this idea at Parent Information Night and visited several classes and spoke to the students about the idea and answered their many questions about how the Reading Challenge worked. We have many enthusiastic students joining in and wanting to be the one who reads the most books. A copy of the Reading Challenge list can be emailed to you.

\section{Conclusion.}

I really feel that we are on a roll with our aim of developing a culture of reading at Mill Park Secondary College. I have never had so many parents keen to talk to me about reading and what the college is doing than I have had this year. Teaching staff are excited about who our next Reading Matters speaker is to be and some ask me to plan our Readers' Cup finals dates around family commitments! But most of all, a lot of our students are keen to be involved in a number of our strategies and rope their friends into participating as well. It is so heartening to see some students at Reading Matters who you never would have dreamed would bother to attend. And when they ask sensible questions and even ask the speaker for a photo, you know that you are doing something right.

So what's next for Mill Park Secondary College'? When I was a guest of the Centre for Children's Literature in Copenhagen in 2001, the wonderful staff there told me about their programme where a special book is published and provided for students at a drastically reduced price to encourage and celebrate reading. I am pursuing a similar concept in Australia where the anthology Kid's Night In is sponsored by Australia Post (Royal Mail) and distributed to every year seven student in Australia during Book Week or Literacy Week. I 
would love to see all our year $7 \mathrm{~s}$ owning this terrific book and dipping into stories written by 90 or so of the world's top authors for children.

So let's all make every week book week! I know that we can all make a difference in many young (and not so young) lives.

I hope that this has given you some practical ideas on how to develop a reading culture at your school. I am very happy to answer any questions and to keep in touch via cmail if you have any queries that you don't think of today. You may email me at way.judith.j@edumail.vic.gov.au

\section{References.}

Jennings, P. (2003). The reading hug...and how you can help your child wo catch it. Penguin, Camberwell, Vic. Kids' Night In (2003). Penguin, Camberwell, Vic.

Moloney, J. (2000). Boys and books: building a culture of reading around our bows. ABC Books, Sydney. Readers' Cup Competition Documents. Available http:/www.edna.edu.au/edna/page2520.html Accessed $29 / 2 / 2004$

Way, J (2002). 'Danish Centre for Children's Literature.' FYI, Winter, pp. 15-17.

Way, J and Phung. R. (2000). 'Staff book club at Mill Park.' FYI, Spring, pp. 12-13.

\section{Author Note}

Judith Way graduated from the University of Melbourne in 1989 with a double degree in teaching and librarianship. She has worked in a variety of government and private schools including Geelong Grammar School. She completed a Master of Applied Science (Teacher Librarianship) in 1999 and is currently completing her final year of a Master of Arts (Children's Literature). She is a reviewer for Fiction Focus, a journal of the Education Department of Western Australia and has had several articles published in FYI, the journal of the School Library Association of Victoria. Judith is currently the Library Resources Co-ordinator at the junior campus of Mill Park Secondary College, 20 kilometres to the north of the city of Melbourne, Australia. 